DOI: $10.15290 /$ bsl.2018.13.03

\author{
Svetlana Pavlenko \\ Wydział Filologiczny \\ Uniwersytet Gdański \\ e-mail: svetlana.pavlenko@onet.pl \\ ORCID: 0000-0002-7443-2856
}

\title{
Syberyjski tekst literatury rosyjskiej we współczesnej myśli humanistycznej
}

\section{Epidemia spacjalna w Rosji}

Jak każde inne miasto - Petersburg ma swój «język». Przemawia swymi ulicami, placami, wodami, wyspami, parkami, gmachami, pomnikami, ludźmi, historią, ideami i może być rozumiany jako swego rodzaju heterogeniczny tekst, któremu przypisuje się pewien ogólny sens i na którego podstawie można zrekonstruować określony system znaków, realizowany w tekście ${ }^{1}$

- to klasyczne sformułowanie Władimira Toporowa dotyczące definicji tekstu petersburskiego było i jest wielokrotnie przytaczane $\mathrm{w}$ pracach badaczy zajmujących się problematyką miejską. Wprowadzając w 1984 roku do obiegu naukowego pojęcie tekstu petersburskiego i przedstawiając mechanizmy „wrośnięcia krajobrazu w kulturę”2, Toporow nie mógł przewidzieć, jakim intelektualnym wyzwaniem dla rosyjskiej humanistyki stanie się jego koncepcja oraz jaką reakcję wywoła.

\footnotetext{
1 W. Toporow, Petersburg i tekst petersburski literatury rosyjskiej. Wprowadzenie do tematu, w: tegoż, Miasto i mit, przeł. B. Żyłko, Gdańsk 2000, s. 73.

2 Por. O.A. Lavrenova, Lokal'nye teksty kul'tury v kontekste kul'turnogo landšafta, „Observatoriâ kul'tury" 2010, nr 6, s. 65.
} 
Filolog i kulturolog Aleksander Lusyj zauważa: „Toporow rzucił metodologiczne wezwanie Rosji i ta odpowiedziała mu na to tekstualną rewolucją wiedzy humanistycznej" ${ }^{3}$. Chodzi tu przede wszystkim o postulat Toporowa zakładający wyjątkowość tekstu petersburskiego, a w konsekwencji nieprzystawalność wypracowanych narzędzi do analizy innych przestrzeni rosyjskich. Tekst petersburski, wedle badacza, występował jako swoisty endemit, dlatego strategie jego opisu nie mogły stanowić wzoru dla pozostałych terytoriów i miast. Pierwsze dyskusje i towarzyszące im „walki metodologiczne" można zaobserwować na przykładzie moskiewskiego tekstu kultury rosyjskiej. Toporow negował istnienie tekstu moskiewskiego, rozpatrując Moskwę jako część tekstu petersburskiego, pozwalającą dookreślić jego tożsamość: „W tekście petersburskim tkwi w jakiejś mierze komponent moskiewski, który decyduje - choć brzmi to paradoksalnie - o swoistym «moskwocentryzmie» tekstu petersburskiego [...]" ${ }^{4}$. Rosyjskim badaczom udało się uzasadnić funkcjonowanie pojęcia tekstu moskiewskiego, co znalazło swój wyraz w monografiach i tomach pokonferencyjnych poświęconych tej problematyce $^{5}$. Ponadto $\mathrm{w}$ ślad za moskiewskim w publikacjach zaczęły się pojawiać inne teksty: krymski, kaukaski, uralski, północny, syberyjski ${ }^{6}$ etc.

Nieprzypadkowo zatytułowałam ten wstęp Epidemia spacjalna; rozpowszechnienie w Rosji praktyk spacjalnych zmierzających do stworzenia nowych tekstów miejskich na wzór petersburskiego osiągnęło swoje apogeum. Tak na przykład $\mathrm{w}$ artykule Na puti $k$ «Kimrskomu tekstu»: teoriâ $i$ praktika

3 Por. A.P. Lûsyj, Tekstual'naâ revolûciâ ili semiotičeskaâ mutaciâ? Ob odnom kul'turologičeskom putešestvii v peterburgskoj maršrutke, konceptualizirovannom probkoj na ulice Pestelâ, „Kul'turologičeskij žurnal" 2012, nr 2(8), http://www.cr-journal.ru/rus/journals/123.html\&jid=10 [dostęp 31.08.2018].

4 W. Toporow, Petersburg $i$ tekst petersburski..., s. 71.

5 Zob. Moskva i "moskovskij tekst" russkoj kul'tury, red. G.S. Knabe, Moskva 1998; Moskva v russkoj $i$ mirovoj literature, red. N.D. Bludilina, Moskva 2000; Moskva i "moskovskij tekst" v russkoj literature XX veka, t. 4, red. N.M. Malygina, Moskva 2007; A.P. Lûsyj, Moskovskij tekst. Tekstologičeskaâ koncepciâ russkoj kul'tury, Moskva 2013 i in. prace.

${ }^{6}$ Wymienię niektóre z prac analizujące teksty regionalne, z wyjątkiem tekstu syberyjskiego, o którym będzie mowa dalej: A.P. Lûsyj, Puškin. Tavrida. Kimmeriâ, Moskva 2000; A.P. Lûsyj, Krymskij tekst $v$ russkoj literature, Sankt-Peterburg 2003; V.I. Šul'ženko, Kavkazskij fenomen russkoj prozy, Pâtigorsk 2001; V.I. Šul'ženko, Russkij Kavkaz: očerki meždisciplinarnyh issledovanij, Pâtigorsk 2007; A.P. Lûsyj, Kavkazskij tekst: plen i mest', w: Geografiâ iskusstva, t. 5, oprac. O.A. Lavrenova, Moskva 2009; V.V. Abašev, Perm' kak tekst. Perm' v russkoj kul'ture i literature XX veka, Perm' 2000; Literaturnyj process na Urale v kontekste istoriko-kul'turnyh vzaimodejstvij: konec XIV-XVIII vv., red. E.K. Sozina, Ekaterinburg 2006; Literatura Urala: istoriâ i sovremennost', t. 1-7, red. E.K. Sozina, Ekaterinburg 2006, 2007, 2008, 2010, 2011, 2012; Severnyj tekst v russkoj kul'ture, red. N.I. Nikolaev, Arhangel'sk 2003; Severnyj tekst russkoj literatury, t. 1-4, red. E.Š. Galimova, Arhangel'sk 2009, 2012, 2013, 2018; Severnyj i Sibirskij teksty russkoj literatury kak sverhteksty: tipologičeskoe i unikal'noe, red. E.Š. Galimova, A.G. Lošakov, Arhangel'sk 2014. 
Władimir Korkunow podejmuje próbę opisu małych prowincjalnych miasteczek, do których należy m.in. rosyjskie miasto Kimry w obwodzie twerskim ${ }^{7}$. Chociaż autorowi udaje się wyodrębnić kilka oryginalnych wątków wplecionych $\mathrm{w}$ tkankę miasta, stopień tekstualizacji i mitologizacji tej przestrzeni nie pozwala rozpatrywać Kimry jako konstrukcji heterogenicznej, o której pisał Toporow. Korkunow słusznie zwraca uwage na dwa problemy dotyczące lokalnych tekstów kultury - nieprecyzyjność samego pojęcia oraz luki w metodologii. Podobne trudności napotykamy nie tylko w kontekście analizy pojedynczych tekstów miejskich, ale też „tekstów regionalnych" obejmujących swoim zasięgiem przestrzenie $\mathrm{w}$ danym regionie państwa rosyjskiego (uralski, północny itp.).

W niniejszym artykule chciałabym uczynić przedmiotem rozważań syberyjski tekst literatury rosyjskiej i skupić się na definicji tego pojęcia oraz jego strukturze. Opisy większych terytoriów, w tym Syberii, niewątpliwie wymagają szerszego podłoża metodologicznego (najlepszym rozwiązaniem wydaje się podejście interdyscyplinarne), dlatego istotnym punktem mojej refleksji będzie przedstawienie szeregu propozycji rosyjskich badaczy zajmujących się metodologicznym ujęciem tego zjawiska. Zamierzam również wskazać na pułapki i miejsca trudne, które należy uwzględniać w tego rodzaju studiach nad przestrzenią.

\section{Tekst syberyjski: granice pojęcia i struktura}

W ostatnich latach wśród rosyjskich naukowców coraz więcej zwolenników zdobywa pojęcie ultratekstu (сверхтекст), które nabrało ostatecznego kształtu w pracach przedstawicieli szkoły tartusko-moskiewskiej ${ }^{8}$. Nowosybirska badaczka Nina Miednis zdefiniowała ultratekst następująco: „to złożony system zintegrowanych tekstów, mających wspólną pozatekstową orientację, tworzących niezamkniętą jedność, dla której charakterystyczna jest spójność znaczeniowa i językowa" ${ }^{9}$. Według Miednis przykłady ultratekstu stanowią teksty miejskie (petersburski, wenecki, rzymski), niektóre teksty prowincjalne (permski) oraz teksty personalne (np. Puszkinowski) ${ }^{10}$. Jeśli ana-

7 V. Korkunov, Na puti k «Kimrskomu tekstu»: teoriâ i praktika, „Voprosy literatury” 2014, nr 6, s. 325-344.

8 Zob. A. Lošakov, Problema sverhteksta v otečestvennoj filologii, „Acta Neophilologica” 2008, nr 10, s. 186.

9 Por. N.E. Mednis, Sverhteksty v russkoj literature, http://rassvet.websib.ru/text.htm?no=35 \&id=3 [dostęp 31.08.2018], przekład autorki.

10 Tamże. 
liza ultratekstów miejskich ma już pewne ścieżki metodologiczne (chociaż i tu można odnotować szereg problemów, które sygnalizował Korkunow), to poszukiwanie istoty ultratekstów regionalnych, a także wypracowywanie skutecznych podejść do tych zjawisk trwa do tej pory, bowiem olbrzymie i mocno zróżnicowane tereny Syberii cechują zupełnie inne właściwości niż pojedynczych przestrzeni miejskich.

Tekst syberyjski, podobnie jak sama Syberia, to pojęcie złożone i wielopoziomowe, wokół którego obecnie toczą się spory o to, jak liczba powstałych tekstów przekłada się na ich jakość oraz o to, czy możemy mówić o Syberii jako kodzie kulturowym ${ }^{11}$. Aleksander Kazarkin podkreśla, że filolodzy nadużywają definicji tekstu syberyjskiego, wpisując w jego ramy każdy przekaz werbalny dotyczący Syberii, a przecież niektórzy autorzy "tekstów syberyjskich" nigdy nie byli w tym regionie, mamy w ich przypadku do czynienia tylko z grą wyobraźni, wachlarzem domysłów ${ }^{12}$, w związku z czym granice pojęcia stają się coraz bardziej płynne, w miejsce bezpośrednio doświadczanej przestrzeni pojawiają się fantazmaty i stereotypy.

We Wstępie do tomu zbiorowego Sibirskij tekst v nacional'nom sûžetnom prostranstve Kiriłł Anisimow pisze, że współcześni literaturoznawcy rozpatrują tekst syberyjski dwojako ${ }^{13}$. Pierwsze podejście zaprezentował Walerij Tiupa, który zaznaczył, że już na początku XIX wieku Syberia zajęła swoje określone miejsce nie tylko na geopolitycznej mapie Imperium Rosyjskiego, ale też w kulturze rosyjskiej. Została poddana stopniowemu procesowi mitologizacji i przedstawiała „pewien sposób obecności człowieka w świecie” 14 . Na podstawie literatury rosyjskiej XIX wieku badacz wyodrębnia łańcuch syberyjskich mitologemów (kraina śmierci/martwych, zimna, zimy i nocy, bezludna i bezkresna) i dochodzi do wniosku, że Syberia stanowi przykład nie infernalnego, lecz liminalnego (przejściowego) chronotopu ${ }^{15}$. Bohater, trafiając na Syberię, doświadcza obrzędu przejścia, którego kluczowe etapy stanowią symboliczna śmierć i odrodzenie. Przypomina to Łotmanowską triadę „zbrodnia - zesłanie na Syberię - zmartwychwstanie”, zastępującą

11 Zob. E.A. Makarova, Specifika bytovaniâ «sibirskogo teksta» v literaturnoj situacii poslednej treti XIX veka, w: Sibirskij tekst v nacional'nom sûžetnom prostranstve, red. K.V. Anisimov, Krasnoârsk 2010, s. 48 .

12 A.P. Kazarkin, Literaturnaâ klassika Sibiri: podhod i definicii, w: Sibirskij tekst v russkoj kul'ture, t. 2, red. A.P. Kazarkin, N.V. Serebrennikov, Tomsk 2007, s. 34.

13 K. Anisimov, Ot redaktora, w: Sibirskij tekst v nacional'nom sûžetnom prostranstve, s. 3.

14 Por. V.I. Tûpa, Mifologema Sibiri: $k$ voprosu o «sibirskom tekste» russkoj literatury, „Sibirskij filologičeskij žurnal" 2002, nr 1, s. 27.

15 Tamże, s. 28. 
często schemat fabularny „śmierć - piekło - zmartwychwstanie" ${ }^{16}$. W takim odbiorze tekst syberyjski przekracza ramy geograficzne i staje się pojęciem historiozoficznym a zarazem metafizycznym. Tiupa wyznaczył w swojej rozprawie kierunek badań, który niewątpliwie wymaga pogłębienia i dalszych poszukiwań, gdyż tematyczny poziom syberyjskiego tekstu zakłada nie jeden scenariusz, lecz ich większą liczbę. Anisimow słusznie wskazuje na utopijny komponent $\mathrm{w}$ strukturze tekstu syberyjskiego, Syberia reprezentowała bowiem nie tylko infernum, ale też bywała drogą do raju (o czym świadczą np. legendy o Białowodziu) ${ }^{17}$.

Drugie podejście do tekstu syberyjskiego zakłada interpretację tego zjawiska w kontekście lokalnego piśmiennictwa i regionalnej tożsamości (kształtowanie się syberyjskiego obłastniczestwa i jego przejawy w kulturowym rozwoju Syberii) ${ }^{18}$. Chodzi tu o zupełnie inny rodzaj odczuwania świata, percepcję Syberii nie jako obcej ziemi, lecz przestrzeni rodzimej, ocenianej w kategorii „swój”. Kazarkin pisze:

Jeśli pod pojęciem tekstu syberyjskiego rozumieć pogląd na świat mieszkańców regionu, wtedy to połączenie wyrazowe staje się terminem. Fale kolonizacji, współzawodnictwo stepowych koczowników i kultur myśliwych tajgi, relikty przedpiśmiennych kultur we współczesności - to wszystko składniki „tekstu syberyjskiego". To nie jest spojrzenie z boku, to punkt widzenia Sybiraków, niezależnie od tego, czy są myśliwymi, czy pisarzami. I to niekoniecznie „Syberia jako mitologem" 19 .

Te dwa podejścia nie wykluczają się nawzajem, podobnie jak literatura o Syberii i literatura syberyjska, lecz stanowią szerokie podłoże do dalszych badań. Walerij Domanski również zwraca uwagę na to, że tekst syberyjski nie mieści się tylko w granicach literatury, w jego skład wchodzą także teksty o charakterze publicystycznym, ideologicznym, naukowym ${ }^{20}$. "Zaha-

16 Por. U..M. Lotman, Sûžetnoe prostranstvo russkogo romana XIX stoletiâ, http://philologos. narod.ru/lotman/russpace.htm [dostęp 31.08.2018].

17 K.A. Anisimov, Paradigmatika i sintagmatika sibirskogo teksta russkoj literatury (Postanovka problemy), w: Sibirskij tekst v russkoj kul'ture, t. 2, s. 65. Zob. też: A. Starzyńska, Kilka uwag o legendarnym Białowodziu - krainie szczęśliwości "na Syberii, czy za Syberia, albo jeszcze gdzieś indziej”, „Opera Slavica” 2016, vol. 26, iss. 1, s. 49-56, https://digilib.phil.muni.cz/bitstream/handle/11 222.digilib/135543/2_OperaSlavica_26-2016-1_7.pdf [dostęp 31.10.2018].

18 K. Anisimov, Ot redaktora, s. 3.

19 Por. A.P. Kazarkin, Literaturnaâ klassika Sibiri: podhod i definicii, s. 34.

20 Badacz zaznacza, że pojmuje tekst syberyjski zarówno jako tekst literacki w ujęciu Toporowa, jak i inne rodzaje tekstów, które odsłaniają "gospodarcze i kulturalne życie regionu, kształtowanie i rozwój regionalnej samoświadomości" [V.A. Domanskij, Strukturnye urouni sibirskogo teksta, w: Sibirskij tekst v russkoj kul'ture, t. 2, s. 50]. 
cza" on o różne dziedziny wiedzy - geografię, geologię, etnologię, historię i inne - które pozwalają na bardziej precyzyjny opis jego wielowarstwowej struktury. Według badacza struktura tekstu syberyjskiego ukształtowała się na początku XX wieku i zawiera następujące poziomy: mitologiczny, folklorystyczny, etnograficzny, geograficzny, przyrodniczo-klimatyczny, socjalny, kulturowo-historyczny ${ }^{21}$. Domanski opisał ponadto pięć modeli syberyjskich tekstów literackich, w których główny element stanowi postać narratora i jego sposób postrzegania rzeczywistości 1) Syberia w odbiorze przedstawiciela centrum i innych części Rosji; 2) Syberia postrzegana przez kosmopolitę; 3) Rosja w oczach Sybiraka; 4) świat w percepcji Sybiraka; 5) Syberia w oczach jej mieszkańców ${ }^{22}$. Każdy z tych modeli może posiadać swoje warianty i dowolnie łączyć się z innymi modelami, czego przykładem jest utwór Iwana Gonczarowa Fregata "Pallada".

Jednak w strukturze tekstu syberyjskiego nakreślonej przez badacza zabrakło dwóch ważnych składników - figury obcokrajowca (badacza, zesłańca, podróżnika) i inorodca (przedstawiciela rdzennych ludów syberyjskich). Tekst syberyjski ma charakter ponadnarodowy, nie jest zjawiskiem należącym wyłącznie do kultury rosyjskiej ${ }^{23}$, dlatego obcojęzyczne świadectwa i punkt widzenia nie-Rosjanina, nie-Sybiraka są nie mniej ważne niż głosy mieszkańców kraju. Ponadto, mówiąc o polskim tekście syberyjskim, chciałabym zwrócić uwagę na fakt, że polscy autorzy tworząc swoją mapę Syberii, inaczej rozkładają akcenty, przyciągają ich inne przestrzenie syberyjskie, które są następnie kodowane przez pryzmat rodzimej kultury poszczególnych autorów. Dzięki temu otwierają się ciekawe perspektywy dla badań komparatystycznych.

Postać inorodca pojawia się nie tylko na poziomie etnograficznym, ale odsyła też do kontekstu kolonialnego, który można rozpatrywać osobno lub połączyć te dwa poziomy w całość, jak zrobiła to w swojej rozprawie Jelena Sozina ${ }^{24}$. Ciekawa wydaje się uwaga badaczki, że analizowany przez nią wogulski etnotekst stanowi część „,szamańskiego” ultratekstu, który ściśle wiąże się z tekstem syberyjskim, ale jednocześnie przekracza jego granice. Na poziomie etnograficzno-kolonialnym ważną rolę odgrywa chronotop podróży

\footnotetext{
21 Tamże, s. 55.

22 Tamże, s. 55-56.

23 Więcej o tym piszę w: S. Pavlenko, Rosja Adama Mickiewicza oraz jego polskich i rosyjskich przyjaciót, Gdańsk 2018.

24 E.K. Sozina, Ètnografičeski-kolonial'nyj subtekst v sostave sibirskogo teksta: po proizvedeniâm K. Nosilova i P. Infant'eva, w: Sibirskij tekst v nacional'nom sûžetnom prostranstve, s. 108-132.
} 
odbywającej się na dwóch płaszczyznach - fizycznej oraz symbolicznej ${ }^{25}$. Należy podkreślić, że podróż była jednym z najważniejszych sposobów odtwarzania i translacji obrazu Syberii w literaturze ${ }^{26}$.

Ujęcie z perspektywy kolonialnej zmienia spojrzenie na całokształt tekstu syberyjskiego - kładzie nacisk na zagadnienia dotyczące relacji centrum - Syberia, ja - Inny, kształtowanie się nowej tożsamości terytorialnej. Biorąc pod uwagę fakt, że struktura tekstu syberyjskiego nie jest statyczna i z biegiem czasu uzupełniają ją nowe komponenty, najprostszym rozwiązaniem wydaje się rozpatrzenie tekstu syberyjskiego w dwóch wymiarach - paradygmatycznym oraz syntagmatycznym - które pozwalają prześledzić mechanizmy semiotycznej transformacji przestrzeni.

Elementy paradygmatyki reprezentują swoisty słownik regionu (np. wyprawa Jermaka ${ }^{27}$, staroobrzędowcy, zesłanie dekabrystów, represje i łagry, wydobywanie surowców mineralnych etc.), przy czym każdemu z tych haseł towarzyszą określone motywy. Dużą rolę w kreowaniu tekstu syberyjskiego odgrywają również poszczególne przyrodnicze elementy krajobrazowe: góry, tajga oraz potężne rzeki, w opisach stanowiące często antytezę rzek płynących w europejskiej części Rosji, a zarazem będące ważnym wyznacznikiem tożsamości terytorium. Tak więc semiotyka jest dobrym narzędziem do rozpoznawania i opisywania pewnych aspektów tekstu syberyjskiego, literaturoznawcy zaś coraz częściej odwołują się do dociekań specjalistów o odmiennej proweniencji - historyków, etnologów, folklorystów, kulturologów, filozofów, co umożliwia bardziej wszechstronne ujęcie tematu.

\section{Dodatkowe orientacje metodologiczne}

Wyzwanie stanowi także to, iż tekst syberyjski wykazuje tendencję do dezintegracji, rozpada się na mniejsze teksty o różnym potencjale generatywnym, w Łotmanowskim rozumieniu mamy do czynienia z sytuacją tekst $\mathrm{w}$ tekście ${ }^{28}$. W skład tekstu syberyjskiego wchodzi np. tekst ałtajski ${ }^{29}$

\footnotetext{
25 Tamże, s. 131.
}

26 Więcej na ten temat zob. K.V. Anisimov, Putešestvie: $k$ voprosu o žanrovoj sostavlâûsej sibirskogo teksta, w: Sibirskij tekst v russkoj kul'ture, red. A.P. Kazarkin, Tomsk 2002, s. 20-30.

27 Jermak - Kozak, zdobywca Syberii, zasłynął walkami z Tatarami, zginął w 1585 roku.

28 Û.M. Lotman, Tekst $v$ tekste, http://www.iedtech.ru/files/journal/2014/1/lotman-text-intext.pdf [dostęp 30.10.2018].

29 Tekst ałtajski jako odmiana tekstu syberyjskiego jest najszerzej opisany w literaturze naukowej. Od 2002 roku w Barnaule ukazują się monografie zbiorowe pt. Altajskij tekst $v$ russkoj kul'ture. 
i tekst tomski. Tekst tomski funkcjonuje jednocześnie na dwóch płaszczyznach - jako miasto prowincjalne oraz osobny fragment struktury tekstu syberyjskiego. Na początku XX wieku Tomsk zyskał swoje niepowtarzalne oblicze semiotyczne, w związku z czym stał się rozpoznawalny wśród innych syberyjskich miast, dla których występował jako wzór, matryca semantycznych dominant ${ }^{30}$. Na tle innych prowincjalnych miast Tomsk wyróżniał się m.in. tym, że był postrzegany jako centrum:

W ciągu dłuższego czasu gubernialny Tomsk, stolica zachodniej Syberii, był odbierany przez mieszkańców regionu jako centrum kulturowe, w którym realizowali oni swoje gospodarcze i duchowe potrzeby, natomiast dalekie stolice, w których wielu z mieszkańców nigdy nie było, przedstawiały się jako pewne substancje mitologiczne ${ }^{31}$.

Należy pamiętać, że do miana syberyjskiej stolicy pretendowały poza Tomskiem różne miasta - Krasnojarsk, Nowosybirsk, Irkuck - co czyni z Syberii jakby odrębny od Rosji kraj, który posiada swoje centra i prowincje. Poczucie osobliwości terytorium nasila się w związku z oddziaływaniem jeszcze jednego czynnika - zamkniętego charakteru Syberii i jej „niedostępności” dla europejskich mieszkańców Rosji (niekiedy łatwiej im dostać się do Europy niż nad Bajkał). Aczkolwiek mówiąc o centrach i prowincjach, warto podkreślić, iż nie każde miasto może posiadać swój własny "tekst”. Aby tak się stało, musi ono spełniać szereg warunków. Nina Miednis pisze:

Najczęściej widzimy w literaturze pewne oczywiste fragmentaryczne formacje tekstowe, pozwalające mówić o obrazie tego czy innego miasta $w$ twórczości określonego pisarza lub szeregu pisarzy, jak o Wiatce w utworach Sałtykowa-Szczedrina, o Tambowie lub Saratowie w literaturze rosyjskiej XIX wieku. Jednak wątpliwe jest, czy można mówić o wiackim bądź tambowskim tekście literatury rosyjskiej $[\ldots]^{32}$.

Tomsk posiada swoją mitologię i zestaw konstytuujących go charakterystyk przestrzennych, pojawia się $\mathrm{w}$ literaturze jako bohater, a przedstawienia jego mieszkańców noszą wiele cech unikatowych. Natomiast w przypadku Krasnojarska bądź Nowosybirska stosowniej jest mówić o reprezentacjach miejskich w poszczególnych tekstach kultury.

30 Zob. V.A. Domanskij, Substraty Tomskogo teksta, w: Severnyj i Sibirskij teksty russkoj literatury..., s. 101.

31 Por. tamże, s. 102.

32 Por. N.E. Mednis, Sverhteksty v russkoj literature, http://rassvet.websib.ru/text.htm?no=35 \&id=8 [dostęp 30.10.2018]. 
Idea centrowości tego czy innego prowincjalnego miasta ściśle wiąże się z kompleksami terytorialnymi, dotkliwym doświadczeniem odległości od centrum. Słusznie zauważa Anisimow, że tekst syberyjski wychodzi poza ramy prowincjonalności i wykazuje raczej powiązania z konceptem peryferii. Szczególnymi oznakami peryferyjności Syberii są, według badacza, jej geograficzna i historyczna izolacja, pozostawiający więcej swobody mieszkańcom w porównaniu do centralnej Rosji typ gospodarki, ambiwalentny charakter klimatu (w zależności od odbiorcy - idealny lub nieznośny), osobliwa etnografia i wierzenia lokalne, postrzeganie Syberii jako obcego kraju ${ }^{33}$. Co więcej, koncept peryferii pozwala zestawić Syberię z innymi przestrzeniami - Petersburgiem, Krymem, Kaukazem, Uralem oraz terenem północnej Rosji.

Najwięcej podobieństw można zauważyć między tekstem syberyjskim a północnym ${ }^{34}$, przede wszystkim na poziomie przestrzennych wyobrażeń o tych terytoriach (bezkresne, pełne tajemnic ziemie, piekło i raj, miejsce zesłania i schronienia, Białowodzie i in.) oraz w charakterystykach mentalności mieszkańca Północy i Sybiraka, o czym wzmiankuje Jelena Galimowa ${ }^{35}$. W swoich studiach nad ultratekstami regionów badaczka opiera się m.in. na podstawowych założeniach etnopoetyki. Północny tekst określa ona jako „północno-rosyjski wariant narodowego obrazu świata, który na równi z indywidualnymi, odzwierciedlającymi swoisty charakter pojmowania świata przez każdego z autorów, posiada również wspólne, typologiczne cechy" ${ }^{36}$. Odtworzenie całokształtu tekstu północnego ma polegać na analizie następujących zagadnień: kategorii czasoprzestrzeni, systemu lejtmotywów zapewniających spójność tekstu, typologicznie bliskich obrazów (głównie mitopoetyckich i folklorystycznych) oraz systemu bohaterów dzieła literackiego ${ }^{37}$. Podobna metodologia może być zastosowana również $\mathrm{w}$ badaniach nad tekstem syberyjskim, oczywiście ze szczególnym uwzględnieniem jego specyficznych cech.

\footnotetext{
33 Por. K. Anisimov, Ot redaktora, s. 5-6.

34 Północna Rosja obejmuje tereny obwodu archangielskiego, wołogodzkiego oraz doliny rzek wpadających do Morza Białego.

35 Zob. E.Š. Galimova, Konceptosfera «volâ//svoboda»v hudožestvennyh kartinah mira Severnogo i Sibirskogo tekstov russkoj literatury, w: Severnyj i Sibirskij teksty russkoj literatury..., s. 211-226.

36 Por. E.Š. Galimova, K voprosu o metodologii issledovaniâ lokal'nyh (gorodskih i regional'nyh) literaturnyh sverhtekstov (na primere Severnogo teksta russkoj kul'tury), w: Sibirskaâ identičnost' v zerkale literaturnogo teksta: tropy, toposy, žanrovye formy XIX-XXI vekov, red. N.V. Kovtun, Moskva 2015, s. 375 .

37 Tamże, s. 379.
} 
Ciekawe wskazówki odnośnie do studiów nad wyobraźnią geograficzną regionu znajdziemy w książkach rosyjskiego geografa i kulturologa Dmitrija Zamiatina, który proponuje uczynić przedmiotem analizy nie geograficzne obrazy Syberii, lecz Zaurale łączące w sobie Syberię i Ural oraz interpretować te obrazy $\mathrm{w}$ kontekście metageografii ${ }^{38}$. Metodologiczne zaplecze metageografii, według Zamiatina, stanowią fenomenologiczne prace Gastona Bachelarda i koncepcje wypracowane $\mathrm{w}$ obrębie semiotyki, poststrukturalizmu oraz postmodernizmu. Ta dziedzina wiedzy skupia się przeważnie na wydobyciu i opisie "egzystencjalnego przeżywania krajobrazów i miejsc - zarówno swoich, jak i obcych"39, a także rekonstrukcji map mentalnych i obrazów poszczególnych terytoriów.

Zamiatin wykreował model przestrzennych wyobrażeń, którego dwa przeciwległe bieguny konstytuują nieświadomość (dół) i świadomość (góra), między nimi zaś wertykalnie ulokowane są cztery poziomy opisu obrazów przestrzennych (od dołu w górę) - obrazy geograficzne, poziom lokalno-mitologiczny, poziom tożsamości regionalnej i krajobrazy kulturowe ${ }^{40}$. Wszystkie poziomy wyobrażeń przestrzennych łączą się ze sobą i tworzą całość za pośrednictwem komponentu ideologicznego, czyli znakowo-symbolicznych reprezentacji, np. tekstów lokalnych, genius loci.

Charakteryzując Syberię wedle swojego schematu, badacz odnotowuje, że ten region posiada wyraźnie zaznaczone obrazy geograficzne i krajobrazy kulturowe, natomiast słabo wyrażoną mitologię lokalną i tożsamość regionalną, co wcale nie oznacza ich zupełnego braku. W mniemaniu Zamiatina Ural reprezentuje kompletny model wyobrażeń przestrzennych, którego główną koncepcję stanowi idea centrum, innymi słowy, Ural przestaje być odbierany jako granica między Europą a Azją i staje się nowym centrum Rosji. Przejście od Uralu do Syberii (bo mówimy o większej strukturze - Zauralu) wymaga ogniwa łączącego, genius loci. Do tej roli najlepiej pasuje sylwetka Jermaka:

\footnotetext{
38 Według Zamiatina metageografia to: „interdyscyplinarna dziedzina wiedzy, na styku filozofii i sztuki (w szerokim znaczeniu) i badająca różne możliwości, warunki, sposoby i dyskursy myślenia i wyobraźni geograficznej. Możliwe synonimy pojęcia metageografia: filozofia krajobrazu, filozofia geograficzna, filozofia przestrzeni (miejsca), geografia egzystencjalna, geozofia, w oddzielnych przypadkach - geografia wyobraźni, imagologia, geopoetyka, poetyka przestrzeni" [D.N. Zamâtin, Strela i šar: vvedenie v metageografiû Zaural'â, w: Sibirskij tekst v nacional'nom sûžetnom prostranstve, s. 7]. Metageografia koreluje z szeregiem innych dyscyplin geopoetyką, geografią sakralną, geografią mityczną, architekturą etc.

39 Tamże, s. 10.

40 Tamże, s. 16.
} 
Jermak występuje jako bohater mitu lokalnego, łączącego bezpośrednio terytoria przed Uralem, sam Ural, Zaurale (głównie zachodnią Syberię). Jest rzeczą znamienną, że popularny lokalny mit ma mnóstwo konkretnych reprezentacji krajobrazowych (konkretne miejsca pamięci, w tym wyraźnie te, w których on nigdy nie mógł być), stanowi podstawę dla kształtowania się przynajmniej kilku tożsamości regionalnych $[\ldots]^{41}$.

Tylko w kontekście zauralskich obrazów, jak twierdzi Zamiatin, Syberia może nabrać ostatecznego kształtu i zaistnieć jako samowystarczalny obraz przestrzenny, gdyż jej metageografia jest jeszcze na drodze rozwoju.

Podsumowując, status Syberii i jej znaczenie w historii i kulturze Rosji, a także innych krajów oraz możliwość powoływania do życia nowych tekstów lokalnych nie budzą wątpliwości. Aby najbardziej precyzyjnie przedstawić tekst syberyjski, należałoby przeanalizować wszystkie teksty literackie oraz pozaliterackie pióra rosyjskich ( $w$ tym osobno syberyjskich) i zagranicznych autorów, u których pojawia się obraz regionu i jego mieszkańców. Oczywiście jest to projekt utopijny, dlatego najczęściej badacze dokonują selekcji, wybierają te teksty kultury, które posiadają wartość artystyczną. Badanie tekstu syberyjskiego stanowi pewne wyzwanie, gdyż wymaga zarówno analizy poszczególnych tekstów wchodzących w skład syberyjskiego, jak i oddzielnych obrazów syberyjskich miast nieposiadających własnych tekstów oraz ogólnych charakterystyk syberyjskiego modelu świata. W tego rodzaju studiach zastosowanie jednej metodologii jest niewystarczające i dlatego tylko współpraca przedstawicieli różnych dyscyplin budzi nadzieję na progres $\mathrm{w}$ rozwiązywaniu tak trudnego zadania. Nie mniej ważne jest wypracowanie własnej koncepcji Syberii, sformułowanie osobistej odpowiedzi na pytanie, czym jest ten region dla każdego z nas. Tylko wtedy możliwa będzie konfrontacja wewnętrznego i zewnętrznego punktu widzenia, próba nawiązania dialogu o miejscu i z miejscem, rekonstrukcja obrazu Innego.

\section{Bibliografia}

Abašev Vladimir Vasil'evič (2000), Perm' kak tekst. Perm' v russkoj kul'ture i literature $X X$ veka, Perm': Izdatel'stvo Permskogo universiteta.

Anisimov Kirill Vladislavovič (2002), Putešestvie: $k$ voprosu o žanrovoj sostavlâûsej sibirskogo teksta, w: Sibirskij tekst v russkoj kul'ture, red. A.P. Kazarkin, Tomsk: Sibirika, s. $20-30$.

41 Por. tamże, s. 23. 
Anisimov Kirill Vladislavovič (2007), Paradigmatika i sintagmatika sibirskogo teksta russkoj literatury (Postanovka problemy), w: Sibirskij tekst v russkoj kul'ture, t. 2, red. A.P. Kazarkin, N.V. Serebrennikov, Tomsk: Izdatel'stvo Tomskogo universiteta, s. $60-73$.

Anisimov Kirill Vladislavovič (2010), Ot redaktora, w: Sibirskij tekst v nacional'nom sûžetnom prostranstve, red. K.V. Anisimov, Krasnoârsk: Sibirskij federal'nyj un-t, s. 3-6.

Bludlina Nataliâ Danilovna [red.] (2000), Moskva v russkoj i mirovoj literature, Moskva: Nasledie.

Domanskij Valerij Anatol'evič (2007), Strukturnye urovni sibirskogo teksta, w: Sibirskij tekst $v$ russkoj kul'ture, t. 2, red. A.P. Kazarkin, N.V. Serebrennikov, Tomsk: Izdatel'stvo Tomskogo universiteta, s. 50-59.

Domanskij Valerij Anatol'evič (2014), Substraty Tomskogo teksta, w: Severnyj i Sibirskij teksty russkoj literatury kak sverhteksty: tipologičeskoe i unikal'noe, red. E.Š. Galimova, A.G. Lošakov, Arhangel'sk: ID SAFU, s. 101-111.

Galimova Elena Šamil'evna [red.] (2009, 2012, 2013, 2018), Severnyj tekst russkoj literatury, t. 1-4, Arhangel'sk: Pomorskij universitet.

Galimova Elena Šamil'evna (2014), Konceptosfera «volâ//svoboda» v hudožestvennyh kartinah mira Severnogo i Sibirskogo tekstov russkoj literatury, w: Severnyj i Sibirskij teksty russkoj literatury kak sverhteksty: tipologičeskoe i unikal'noe, red. E.Š. Galimova, A.G. Lošakov, Arhangel'sk: ID SAFU, s. 211-226.

Galimova Elena Šamil'evna, Lošakov Aleksandr G. [red.] (2014), Severnyj i Sibirskij teksty russkoj literatury kak sverhteksty: tipologičeskoe i unikal'noe, Arhangel'sk: ID SAFU.

Galimova Elena Šamil'evna (2015), K voprosu o metodologii issledovaniâ lokal'nyh (gorodskih i regional'nyh) literaturnyh sverhtekstov (na primere Severnogo teksta russkoj kul'tury), w: Sibirskâ̂ identičnost' v zerkale literaturnogo teksta: tropy, toposy, žanrovye formy XIX-XXI vekov, red. N.V. Kovtun, Moskva: FLINTA, s. 365-380.

Kazarkin Aleksandr Petrovič (2007), Literaturnaâ klassika Sibiri: podhod i definicii, w: Sibirskij tekst $v$ russkoj kul'ture, t. 2, red. A.P. Kazarkin, N.V. Serebrennikov, Tomsk: Izdatel'stvo Tomskogo universiteta, s. 32-43.

Knabe G.S. [red.] (1998), Moskva i "moskovskij tekst" russkoj kul'tury, Moskva: RGGU.

Korkunov Vladimir (2014), Na puti k «Kimrskomu tekstu»: teoriâ i praktika, „Voprosy literatury", nr 6, s. 325-344.

Lavrenova Ol'ga Aleksandrovna (2010), Lokal'nye teksty kul'tury v kontekste kul'turnogo landšafta, "Observatoriâ kul'tury”, nr 6, s. 62-67.

Lošakov Aleksandr (2008), Problema sverhteksta v otečestvennoj filologii, „Acta Neophilologica", nr 10, s. 181-189.

Lotman Ûrij Mihajlovič (2014), Tekst v tekste, http://www.iedtech.ru/files/journal/ 2014/1/lotman-text-in-text.pdf.

Lotman Ûrij Mihajlovič (2005), Sûžetnoe prostranstvo russkogo romana XIX stoletiâ, http://philologos.narod.ru/lotman/russpace.htm.

Lûsyj Aleksandr Pavlovič (2000), Puškin. Tavrida. Kimmeriâ, Moskva: Âzyki russkoj kul'tury. 
Lûsyj Aleksandr Pavlovič (2003), Krymskij tekst v russkoj literature, Sankt-Peterburg: Aletejâ.

Lûsyj Aleksandr Pavlovič (2009), Kavkazskij tekst: plen i mest', w: Geografiâ iskusstva, t. 5, oprac. O.A. Lavrenova, Moskva: Institut Naslediâ, s. 75-108.

Lûsyj Aleksandr Pavlovič (2012), Tekstual'naâ revolûciâ ili semiotičeskaâ mutaciâ? Ob odnom kul'turologičeskom putešestvii v peterburgskoj maršrutke, konceptualizirovannom probkoj na ulice Pestelâ, „Kul'turologičeskij žurnal”, nr 2(8), http://www.cr-jour nal.ru/rus/journals/123.html\&j_id=10.

Lûsyj Aleksandr Pavlovič (2013), Moskovskij tekst. Tekstologičeskaâ koncepciâ russkoj kul'tury, Moskva: Veče, Russkij impul's.

Makarova Elena Antoninovna (2010), Specifika bytovaniâ «sibirskogo teksta» v literaturnoj situacii poslednej treti XIX veka, w: Sibirskij tekst v nacional'nom sûžetnom prostranstve, red. K.V. Anisimov, Krasnoârsk: Sibirskij federal'nyj un-t, s. 46-62.

Malygina N.M. [red.] (2007), Moskva $i$ "moskovskij tekst” v russkoj literature XX veka, t. 4, Moskva: MGPU.

Mednis Nina Eliseevna, Sverhteksty v russkoj literature, http://rassvet.websib.ru/text. htm?no=35\&id=3.

Nikolaev N.I. [red.] (2003), Severnyj tekst v russkoj kul'ture, Arhangel'sk: Pomorskij universitet.

Pavlenko Svetlana (2018), Rosja Adama Mickiewicza oraz jego polskich i rosyjskich przyjaciót, Gdańsk: Wydawnictwo Uniwersytetu Gdańskiego.

Sozina Elena Konstantinovna [red.] (2006), Literaturnyj process na Urale v kontekste istoriko-kul'turnyh vzaimodejstvij: konec XIV-XVIII vv., Ekaterinburg: Soûz pisatelej.

Sozina Elena Konstantinovna [red.] (2006, 2007, 2008, 2010, 2011, 2012), Literatura Urala: istoriâ $i$ sovremennost', t. 1-7, Ekaterinburg: Uro RAN, Izdatel'skij dom «Soûz pisatelej», Izdatel'stvo Ural'skogo universiteta.

Sozina Elena Konstantinovna (2010), Ètnografičeski-kolonial'nyj subtekst v sostave sibirskogo teksta: po proizvedeniâm K. Nosilova i P. Infant'eva, w: Sibirskij tekst v nacional'nom sûžetnom prostranstve, red. K.V. Anisimov, Krasnoârsk: Sibirskij federal'nyj un-t, s. 108-132.

Starzyńska Aleksandra, Kilka uwag o legendarnym Białowodziu - krainie szczęśliwości "na Syberii, czy za Syberia, albo jeszcze gdzieś indziej”, "Opera Slavica” 2016, vol. 26, iss. 1, s. 49-56, https://digilib.phil.muni.cz/bitstream/handle/11222.digilib/135 543/2_OperaSlavica_26-2016-1_7.pdf.

Šul'ženko Vâčeslav Ivanovič (2001), Kavkazskij fenomen russkoj prozy, Pâtigorsk: PâtGFA.

Šul'ženko Vâčeslav Ivanovič (2007), Russkij Kavkaz: očerki meždisciplinarnyh issledovanij, Pâtigorsk: Pâtigorskaâ GFA.

Toporow Władimir (2000), Petersburg i tekst petersburski literatury rosyjskiej. Wprowadzenie do tematu, w: tegoż, Miasto i mit, przeł. B. Żyło, Gdańsk: Słowo/Obraz Terytoria, s. 49-142.

Tûpa Valerij Igorevič (2002), Mifologema Sibiri: k voprosu o «sibirskom tekste» russkoj literatury, „Sibirskij filologičeskij žurnal”, nr 1, s. 27-35. 
Zamâtin Dmitrij Nikolaevič (2010), Strela i šar: vvedenie v metageografiù Zaural'â, w: Sibirskij tekst $v$ nacional'nom sûžetnom prostranstve, red. K.V. Anisimov, Krasnoârsk: Sibirskij federal'nyj un-t, s. 7-26.

\title{
The Siberian Text of Russian Literature in the Contemporary Humanities
}

\begin{abstract}
The article focuses on the Siberian text of Russian literature - its definition and structure. Referring to Toporov's concept, which has become an intellectual and methodological challenge for Russian researchers, the author points out that Toporov emphasized the uniqueness of the Saint Petersburgian text, whereas in the Russian humanities, apart from the Moscow text, a number of regional/local texts were created: Crimean, Caucasian, Ural, and Siberian. The specificity of regional texts, including Siberian, requires a broader methodological basis (interdisciplinary approach). Therefore the article analyzes several proposals by Russian researchers regarding the methodological approach to this cultural phenomenon. In addition, it indicates pitfalls and difficulties which should be taken into account in this type of spatial study.
\end{abstract}

Keywords: space, poetics, cultural studies, topographical discourse, region 